\title{
Incognito ergo sum. O wytwarzaniu obojętności
}

\author{
Joanna Tokarska-Bakir
}

\begin{abstract}
Abstrakt: Autorka analizuje różne odcienie obojętności nieżydowskich mieszkańców Warszawy w latach czterdziestych wobec losu żydowskich Polaków. Punktem wyjścia jest zdanie Krzysztofa Dunin-Wąsowicza, historyka i działacza „Żegoty”, który stwierdził, że dla około 75 procent mieszkańców Warszawy „obojętne było to, co działo się poza murem getta”. Powołując się na tezę Thomasa Kühnego, że to właśnie obojętność Niemców wobec Żydów - a nie nienawiść w stosunku do nich - „spowodowała masowe poparcie nazistowskiej polityki rasowej w latach trzydziestych”, autorka zastanawia się, czy „podobnej opinii nie można by sformułować pod adresem” 75 procent mieszkańców Warszawy. Materiał do analizy stanowią w znacznej mierze publikacje prasy ZWZ-AK, w tym przede wszystkim „Biuletyn Informacyjny”.

Wyrażenia kluczowe: żydowscy i nieżydowscy Polacy, obojętność, Zagłada, świadkowie-sprawcy-ofiary
\end{abstract}

Krzysztof Dunin-Wąsowicz, historyk i działacz „Żegoty”, mówi: „moim zdaniem dla jakichś 75 procent ludności [Warszawy] obojętne było to, co działo się poza murem getta". Tę wypowiedź świadka potraktujmy jako umowne otwarcie tematu, nie podejmując z nią dyskusji, tak samo, jak z wyrażoną dalej opinią Profesora, że „takich, którzy z różnych powodów [...] wydawali Żydów Niemcom, było [...] nie więcej niż 10 procent" (Dunin-Wąsowicz, 2013, s. 28) ${ }^{1}$, z czego wynika, że pozostałe 15 musiało być chyba zaangażowane w ratowanie. Dyskusji nie podejmuję, aby nie wchodzić w spór o liczby, a przede wszystkim jednak dlatego, że przedmiot mojego namysłu - obojętność - leży poza skrajnościami: wrogością i solidarnością. Leży teoretycznie, bo jak wynika z lekcji szarej strefy Primo Leviego, każda tematyzacja moralnej ambiwalencji pociąga za sobą zaburzenie pozycji skrajnych i zburzenie rozpiętej na nich polityki symetrii. Uwydatniając skrajności, polityka symetrii każe im ze sobą konkurować, tak jak w polskim dyskursie publicznym szmalcownicy konkurują ze Sprawiedliwymi, pozostawiając w cieniu zagadnienie masowej obojętności. Tymczasem, jak pisze Thomas Kühne, autor Belonging and Genocide. Hitler's Community, 1918-1945: „Nie tyle nienawiść do Żydów, ale właśnie obojętność w stosunku do nich - milczący lub pasywny współudział - spowodowała masowe poparcie nazistowskiej polityki rasowej w latach trzydziestych" (Kühne, 2011, s. 40)². Chciałabym zastanowić się, czy podobnej opinii nie można by sformułować pod adresem owych umownych 75 procent i ich wpływu na los żydowskich Polaków w latach czterdziestych.

1 Zob. też inną wypowiedź Profesora: „Trzy czwarte społeczeństwa, moim zdaniem, pozostawało kompletnie bierne. Bierność wobec Żydów była silniejsza niż wrogość. Trudno się dziwić skali obojętności, bo za pomoc Żydom groziła kara śmierci. Jako osoba pomagająca Żydom z punktu widzenia prawa hitlerowskiego zasłużyłem na wielokrotną karę śmierci. Jednak strach przed śmiercią było mi pokonać łatwiej niż postawę bierności większości ludzi. Ona najbardziej utrudniała niesienie pomocy" (kospa, 2013).

2 "It was not so much the hatred of Jews but indifference toward them - a silent or passive complicity - that established mass support of Nazi racial politics in the 1930s." 


\section{Nieobojętność}

Według Słownika języka polskiego pod redakcją Witolda Doroszewskiego obojętność to „pozostawanie [...] nieczułym w stosunku do kogo lub czego, niewrażliwość na co, nie interesowanie się [czymś]" (Doroszewski, 1963, s. 504). Starsze słowniki polszczyzny - być może ze względu na Apokalipsę św. Jana 13, $15-17$ („Obyś był zimny albo gorący! A tak, żeś letni, a nie gorący ani zimny, wypluję cię z ust moich") - piętnują obojętność za jej moralną ambiwalencję. Starszy o lat sto pięćdziesiąt Stownik Samuela Lindego wzmiankuje ją w rzeczownikowej postaci „obojętki” (łac. ambidexter) - człowieka ni ciepłego, ni zimnego („potrzeba chrześcijaninowi, znającemu prawdę bożą, aby nie był obojętką"), tym bardziej pejoratywnie, że drugie znaczenie „obojętki” to obłuda, zdrada (Linde, 1951, s. 403).

Podobnie jak w sensie leksykalnym, tak w empirycznym obojętność nie jest łatwa do badania. W większości przypadków stanowi pseudonim czegoś innego, odsyłacz do zjawisk mniej rzucających się w oczy albo z pewnych powodów ukrywanych. Chciałabym sprawdzić, czy i w jak uzasadniony sposób ów regressus ad infinitum obojętności ulega zatrzymaniu. Chciałabym uchwycić moment, w którym obojętność nie odsyła już do niczego innego poza sobą, sama sobie przyświadczając jako czemuś, co oczywiste, spotecznie aprobowane.

Rozpocznijmy od różnicowania, czyli wskazania postaw i zjawisk, z którymi można ją pomylić. Analizując wojenne pamiętniki nieżydowskich Polaków, Feliks Tych wymieniał następujące, niebędące obojętnością, przyczyny milczenia dokumentów na temat Zagłady (Tych, 1999, s. 27):

» obawę przed dekonspiracją, gdyby pamiętnik wpadł w niepowołane ręce,

» bezradność i „brak słów”,

》 samoobronę przed uświadomieniem sobie własnej sytuacji (skoro, jak skądinąd błędnie pisał Jeremi Przybora, „staliśmy w tej samej kolejce do nazistowskiej zagłady”) (Tych, 1999, s. 30).

Do tej listy można jeszcze dodać:

» niedoinformowanie,

» koncentrację na własnym losie,

»freezing, zamrożenie reaktywne, podpadające pod psychologiczną regułę, zgodnie z którą im dłużej ociągamy się z działaniem, tym mniejsza szansa, że w ogóle je podejmiemy ${ }^{3}$.

Na poziomie źródeł obojętność przejawia się przede wszystkim prywatywnie - jako nieobecność. Taka, jak brak wpisu dotyczącego powstania w getcie w pamiętniku Andrzeja

3 Na filmie z 1964 roku zatytułowanym Przypadek, w reżyserii Larry’ego Peerce’a, dwóch chuliganów terroryzuje ludzi w nowojorskim metrze. Przemoc dlatego jest tu tak skuteczna, poniewaź świadkowie incydentu, którzy w porę nie zareagowali, z minuty na minutę potęgują swoją bierność, popadając we freezing (Zerubavel, 2006, s. 55). 
Trzebińskiego, poety, który „niemal każdego dnia zapisuje swoje przeżycia”, a pod datą 19 kwietnia nie notuje nic (Grochowska, 2012, s. 108). Albo jako uwydatniająca ów brak obecność - gdy getto płonie, „Sztuka i Naród”, pismo, z którym poeta się identyfikuje, ani razu o tym nie wspomina, za to drukuje w dwóch numerach artykuł kapelana i ideologa Konfederacji Narodu, księdza Józefa Warszawskiego. Śmierć Żydów, synonim domniemanego „partykularyzmu” (jak napisze „Wielka Polska” 5 maja 1943 roku, „walka w getcie nie ma żadnego związku ze sprawą polską") (Libionka, 2006, s. 83, przyp. 376), zostaje tu „przykryta” - czy, jak powiedziałaby Elżbieta Janicka, „obstawiona” - frazesami o katolickim „uniwersalizmie”. Jeszcze wymowniejsza „nieobecność poprzez nadobecność” pojawia się, gdy inny organ Konfederacji, „Nowa Polska”, ubolewa, że wskutek powstania w getcie zniszczeniu ulega cała dzielnica Warszawy (Grochowska, 2012, s. 110). Podobną inwencję przejawiał wcześniej organ Delegatury Rządu, „Wiadomości Polskie”, które w stworzeniu getta widziały raczej szykanę dla etnicznych Polaków: „W tragicznej sytuacji znalazła się uboga ludność polska, która po zamknięciu dla niej dostępu do dzielnicy niemieckiej nie mogła sobie znaleźć gdzie indziej dachu nad głową. Poważnie zostały również zagrożone interesy Zarządu Miejskiego" itd. (Libionka, 2006, s. 29).

Na podstawie silnych poszlak - takich, jak np. wzmianki o złym odbiorze przemówień żydowskich posłów w Radzie Narodowej, Liebermana i Schwarzbarta (Libionka, 2006, s. 33) lub o protestach przeciwko tekstom o żydowskim cierpieniu w „Biuletynie Informacyjnym" (Opracowanie KG AK z wiosny 1944; cyt. za: Libionka, 2006, s. 128) czy artykuł Za murami getta w „Wiadomościach Polskich” (Libionka, 2006, s. 151) - możemy zakładać, że przykłady, które dotąd przytoczyłam, nie tylko nie kwalifikują się jako obojętność, ale stanowią jej przeciwieństwo: przemilczanie. „Rzeczywiście, ten temat [Holokaust] nie istniał - mówi Tadeusz Rolke, w czasie wojny członek Szarych Szeregów. - Kiedy wywożono tysiące ludzi do getta, harcerze śpiewali piosenki. Kiedy płonęło getto, ćwiczyliśmy śpiewanie i śledzenie wroga. Nikt nie mówił, że jest Treblinka” (Rolke, 2013, s. 88).

Milczącego świadka - pisze Eviatar Zerubavel - często uważa się za tego, który nie tylko przyzwala, ale wręcz poduszcza do zbrodni, jako że nie przeciwstawiając się okrucieństwu, de facto je uprawomocnia4. W tym duchu Leon Fejner reaguje na milczenie Szmula Zygelbojma w depeszy z 2 października 1942 roku: „Wysłaliśmy w tej sprawie [zagłady getta w Wielkiej Akcji] trzy iskrówki. Żadnej odpowiedzi od Was. Przemilczanie [...] jest dla nas gorszym ciosem niż bandycka akcja Hitlera” (Libionka, 2006, s. 48). Badacze zmowy społecznej podkreślają, że jak każdy rodzaj pomijania - przemilczanie jest jego odmianą - jest ono pracą wymagającą koncentracji i inwencji, pozostawania w gotowości do stłumienia 5 . Testem różnicującym przemilczenie bywają sytuacje, gdy, ujawniając utajone napięcie, od bezruchu przechodzi się nagle do agresji, jak w kolejnym

4 „Silent bystanders act as enablers because watching others ignore something encourages one to deny its presence” (Zerubavel, 2006, s. 55).

5 „Like silence, denial involves active avoidance. Rather than simply failing to notice something, it entails a deliberate effort to refrain from noticing it. Furthermore, it usually involves refusing to acknowledge the presence of things that actually beg for attention, thereby reminding us that conspiracies of silence revolve not around those largely unnoticeable matters we simply overlook but, on the contrary, around those highly conspicuous matters we deliberately try to avoid" (Zerubavel, 2006, s. 34). 
przykładzie. W artykule Dariusza Libionki, czytamy, że „Rzeczpospolita Polska”, ukazujący się od marca 1941 roku organ prasowy Delegatury Rządu, niemal nie zauważył tematu, jakim był los Żydów (Libionka, 2006, s. 28). Tym wymowniej prezentuje się pogląd na Łamach tego pisma z 14 października 1942 roku, gdy „uparte milczenie o męczeństwie żydowskim”, milczenie poniekąd własne, przypisane zostaje „wielkiej grze politycznej kół żydowskich, przewidującej prędzej czy później powrót dobrych stosunków żydowsko-niemieckich" (Libionka, 2006, s. 42).

\section{Adiaforyzacja $^{6}$}

Uznając obawę, bezradność, samoobronę, niedoinformowanie, egocentryczność czy freezing za wyjaśnienie czyjejś obojętności czynimy założenie, że musi ona w ogóle mieć wyjaśnienie. Jeszcze głębiej ukryte jest założenie, że wobec naoczności nieszczęścia odruchy moralne - solidarności czy współczucia - są bezwarunkowe, co oznacza że powinny uruchamiać się zawsze, skoro, jak twierdził na przykład Emmanuel Lévinas, wiążą się z samym ukonstytuowaniem podmiotu. Gdy znajdzie się słuszny powód, mogą jednak zostać stłumione. Słuszny powód nie jest w ogóle potrzebny tam, gdzie „podmiot drzemie”, co jako „charakterystyczne dla współczesnego społeczeństwa przemysłowego zobojętnienie moralne w stosunku do działań niezwiązanych bezpośrednio ze sferą osobistych doświadczeń" (H. Mommsen, Anti-Jewish Politics and the Interpretation of Holocaust; cyt. za: Bauman, 2009, ss. 395-396) opisywano w niemieckim kontekście Zagłady. Władze hitlerowskich Niemiec wykorzystywały tę obojętność, nie tyle mobilizując, ile raczej neutralizując „typowe uczucia, jakie żywili Niemcy w stosunku do Żydów” (Bauman, 2009, s. 381) 7 .

Jedną z metod tworzenia dystansu było rozpuszczanie pogłosek o domniemanym żydowskim mordzie rytualnym. Melisa Maschmann, wysoka funkcjonariuszka Hitlerjugend, wspomina o szkoleniu z 1939 roku, na którym opowiadał o nim prelegent:

„Podejrzewałyśmy, że opowiadał kompletne bzdury. Ale nikt nie dopuszczał do siebie myśli, że ten nonsens był śmiercionośną trucizną zagrażającą życiu wielu Żydów. Dziś wiem, że bajki o mordzie rytualnym są zmyślone i musiały być rozpuszczane wśród ludzi, żeby szewc Müller niczego nie podejrzewał, gdy jego sąsiad Majer pewnego dnia został wyciągnięty z łóżka, by już nigdy nie wrócić" (cyt. za: Żyndul, 2011, s. 216).

O znaczeniu, jakie kierownictwo hitlerowskie przywiązywało do wątku legend o krwi, świadczy też list Heinricha Himmlera, skierowany 19 maja 1943 roku do SS Gruppenführera Kaltenbrunnera, szefa policji berlińskiej:

6 Zygmunt Bauman pisze, że organizacja społeczna „renders social action adiophoric (originally, adiophoron meant a thing declared indifferent by the Church) - neither good nor evil, measurable against technical (purpose-oriented or procedural) but not moral values" (Bauman, 1999, s. 215).

7 Tak Bauman w oparciu o konkluzje Martina Broszata (Broszat, 1986). Bauman cytuje też następującą wypowiedź D. E. Showalter: „Przede wszystkim chciano uporać z obrazem «Żyda z sąsiedztwa» - znajomego lub wspólnika, który żył obok i oddychał tym samym powietrzem, i który samą swoją obecnością wydawał się zaprzeczać owemu negatywnemu stereotypowi «mitycznego Żyda»" (Showalter, 1982, s. 85; cyt. za: Bauman, 2009, s. 385). 
„Drogi Kaltenbrunnerze, zamówiłem sporą ilość kopii książki Der jüdische Ritualmord [Hellmuta Schramma] i rozpowszechniłem je wśród osób ze stopniem powyżej Standartenführera [pułkownik w SS]. Należy wdrożyć wykrywanie mordów rytualnych wśród Żydów, których jeszcze nie ewakuowano. Proszę mnie informować o każdym odkrytym przypadku. Przygotujemy kilka procesów dla tej kategorii zbrodni. W takich krajach, jak Rumunia, Węgry czy Bułgaria, problemem mordów rytualnych powinni zajmować się eksperci. Uważam, że powinniśmy te przypadki mordów rytualnych przekazać prasie, aby ułatwić sobie ewakuację Żydów z tych krajów" (cyt. za: Bronner, 2007, s. 393).

Opierający się na podobnych zabiegach proces budowania dystansu Zygmunt Bauman nazywa adiaforyzacją - zobojętnianiem ${ }^{8}$. Służy on usuwaniu skutków określonego działania wymierzonego w mniejszość z obszaru refleksji moralnej tzw. „zwykłych ludzi” (Bauman, 2009, s. 437), stopniowo przekonywanych, że z tamtymi nie mają nic wspólnego.

\section{Klasyfikacje - aparat do wytwarzania obojętności}

Po wybuchu wojny podobne procesy adiaforyzacji - zobojętniania gwałtownie szerzyły się też w Polsce i obok innych czynników ${ }^{9}$ zdecydowały o braku społecznego sprzeciwu wobec losu, jaki spotkał żydowskich współobywateli. Trafiły jednak na żyzny grunt, przygotowywany narastającym od roku 1935 nieoficjalnym rasizmem Drugiej Rzeczpospolitej, udokumentowaną przez Ronalda Modrasa (Modras, 2004) zmasowaną propagandą Kościoła katolickiego, a jeszcze wcześniej „antyżydokomunistyczną” propagandą z okresu wojny polsko-bolszewickiej (Szczotka, b.d.) ${ }^{10}$, budzącej pierwotny lęk przed atakiem na trzy świętości - ograniczone dobra:

» religię (plakat $\mathrm{nr} 1$ ),

» substancję biologiczną grupy (lęk przed degeneracją, której symbolem był negroidalny potwór z plakatu nr 2, łączący w sobie cechy Azjaty i Żyda),

» przekazicielkę tej substancji, tj. kobietę (plakat nr 3).

O ile traktat mniejszościowy z roku 1919 gwarantował polskim Żydom „formalne równouprawnienie" (Libionka, 2006, s. 17), a bojkotowana przez prawicę kategoria wspólnoty obywatelskiej obejmującej Polaków wyznania mojżeszowego mogłaby zostać od biedy uznana za prawomocny język polskich władz, w latach trzydziestych ten język zanika. Najsilniejszy wyraz tendencja segregacyjna uzyskuje w roku 1937 w deklaracji powołanego z inicjatywy marszałka Rydza-Śmigłego Obozu Zjednoczenia Narodowego (OZN) (Majchrowski, 1985). Głosi ona, że „gospodarzem w państwie polskim jest naród polski”, dla którego Żydzi stanowią zagrożenie gospodarcze i kulturalne (Libionka, 2006, s. 17). W odróżnieniu od wcześniejszego Bezpartyjnego Bloku Współpracy z Rządem (BBWR), Żydzi nie mogli ubiegać się o przynależność do OZN, co argumentowano tym, że przecież Polacy także nie mogą przystępować do organizacji syjonistycznych. Jak wynika

8 „Adiaphoron - oznaczało rzecz uznaną przez Kościół za obojętną dla wiary” (Bauman, 2009, s. 436).

9 Takich, jak przekonanie o powszechnym poparciu władzy sowieckiej udzielanym przez Żydów.

10 Dziękuję Wojciechowi Wilczkowi za udostępnienie mi fotografii plakatów z okresu wojny polsko-bolszewickiej.

SLH 2/2013 | str. 398 


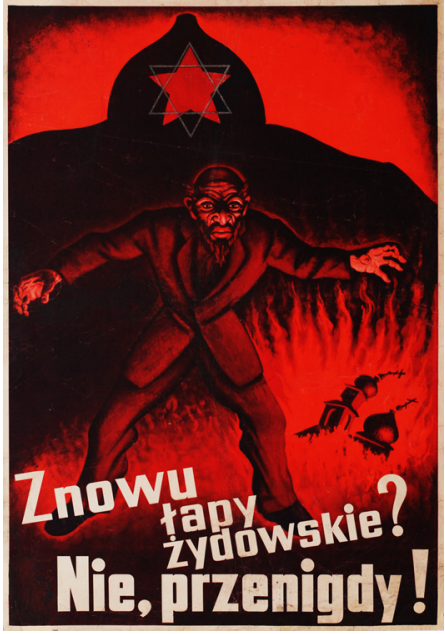

graficzny sylogizm:

„komuniści” to „Żydzi”

- lęk przed bezbożnym ateizmem ${ }^{11}$

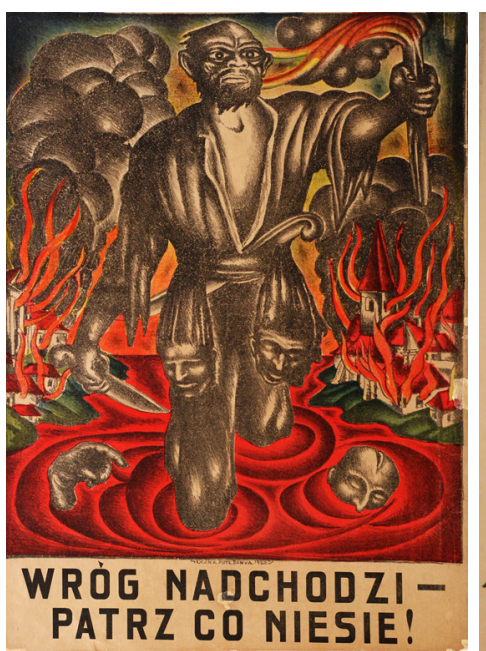

topos „czarnego Żyda” jako bolszewika „Azjaty”

(Gilman, 1986) ${ }^{12}$

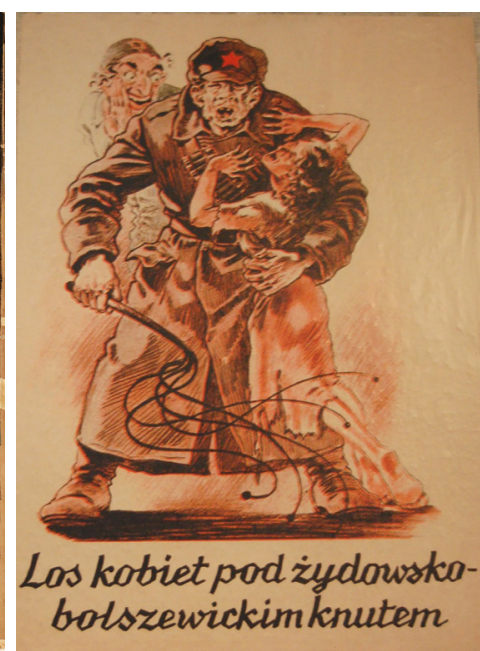

„żydobolszewizm” -

zagrożenie dla polskich dziewcząt ${ }^{13}$

z zaczerpniętego z „Gazety Polskiej” przykładu („Czy Żyd może należeć do OZN”, 1937; cyt. za: Libionka, 2006, s. 17), podstawą ekwiwokacji było redukowanie kategorii obywatelskich („Polak”) i religijnych („żyd”) do etnicznych, co było charakterystyczne dla Polski lat trzydziestych ${ }^{14}$. Realia tuż przedwojenne przypomina wypowiedź Zygmunta Żuławskiego, członka władz centralnych PPS ze stycznia 1939 roku, komentująca interpelację OZN w sprawie środków realizacji masowej emigracji dla radykalnego zmniejszenia liczebności Żydów w Polsce:

„Przecież to straszne żyć w warunkach, w których ustawodawstwo gwarantuje wszystkim równe prawa - i czuć, że wbrew temu jest się tolerowanym jak z łaski, że jest się traktowanym jak zapowietrzony, odosobnionym od społeczeństwa jak trędowaty - dlatego tylko że się urodziło Żydem. To straszne czekać, kiedy człowieka w końcu «wyemigrują» z rodzinnego miasta i ziemi - «dobrowolnie» czy pod przymusem - zależnie od tego czy «międzynarodowe porozumienie» pozwoli rozwiązać ten problem" (Żuławski, 1939, s. 225; cyt. za: Rudnicki, 2008, ss. 208-209).

To ostatnie sformułowanie stanowi aluzję do „nacisków zagranicznych” (powszechnie uznawanych za „żydowskie”15), które w powszechnej opinii wytworzyły polski wariant Dolchstoßlegende - niemieckiej legendy o rzekomo zadanym przez Żydów „ciosie w plecy”, co doprowadziło do krzywdzącego Niemcy traktatu wersalskiego ${ }^{16}$. Od wspomnianego już

11 Plakat Piotra Danya (1920) ze zbiorów Muzeum Niepodleglości w Warszawie (sygn Pl.2011). @ Copyright by Muzeum Niepodległości w Warszawie.

12 Plakat Piotra Danya (1920) ze zbiorów Muzeum Niepodleglości w Warszawie (sygn. Pl.2043). @ Copyright by Muzeum Niepodległości w Warszawie.

13 Plakat ze zbiorów Muzeum Historycznego Miasta Krakowa (sygn. D1909). @ Copyright by Muzeum Historyczne Miasta Krakowa.

14 Zgadza się to z charakterystyczną dla nowoczesnych nacjonalizmów tendencją zaobserwowaną przez Rogersa Brubakera (Brubaker, 2004), że poszerzanie bazy narodu wiąże się z zawężaniem jego definicji do etniczności. W Polsce tendencja ta występowała zarówno wcześniej [,nawet ci, którzy przed kilkoma laty nazywali ich Polakami wyznania mojżeszowego, dziś zwą ich Żydami” (Prus, 1991, ss. 260-261)], jak i później [zob. wstęp do drugiego wydania deklaracji OZN (Deklaracja ideowo-polityczna Obozu Zjednoczenia Narodowego, 1946, s. 11)].

15 Zob. charakterystyczna antyżydowska broszura Franciszka Bujaka, The Jewish Question in Poland (Bujak, 1919).

16 W wariancie polskim przekaz ten odzywa się także we współczesnym artykule Aleksandry Krawczyk (Krawczyk, 2012). 
traktatu mniejszościowego z roku $1918^{17}$ naciski te stanowiły ważną motywację polskich władz, aby uregulować dramatycznie złe stosunki z mniejszościami. Także w okresie drugiej wojny światowej motyw ten - jako uzasadnienie wagi przywiązywanej do położenia polskich Żydów - powraca w korespondencji pomiędzy rządem w Londynie i władzami Polskiego Państwa Podziemnego ${ }^{18}$.

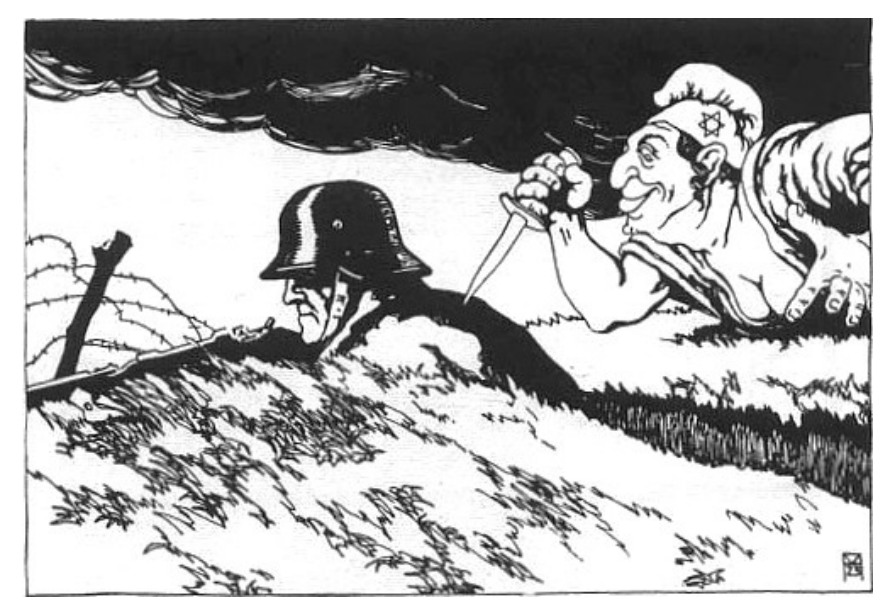

Legenda o ciosie w plecy (niem. Dolchstoßlegende) na pocztówce austriackiej z roku 1919 („Stab-in-the-back myth”, b.d.)

W Nowoczesności i Zagładzie Zygmunt Bauman opisuje organizację społeczną jako „maszynę”, która odpowiedzialność moralną utrzymuje w stanie zawieszenia: „odpowiedzialność ta nie obciąża nikogo, ponieważ wkład poszczególnych jednostek w ostateczny efekt działania jest zbyt mały i zbyt fragmentaryczny, by można mu było zasadnie przypisać funkcję sprawczą" (Bauman, 2009, s. 437). W okupowanej Polsce odpowiedzialność moralną w stanie zawieszenia utrzymywał narzucony przez okupanta system klasyfikacji, którego wpływ na jego beneficjentów - tych, którzy pozostali poza murem - sprowadzał się do sugestii „nie mam z tamtymi nic wspólnego"19. System nie mógłby jednak zadziałać, gdyby nie odwoływał się do wcześniejszych taksonomii. Można wysunąć tezę, że obojętność owych umownych 75 procent, o których mówił Krzysztof Dunin-Wąsowicz, była rezultatem zaakceptowania przez ogół polskich obywateli podziału na uprzywilejowanych Polaków nieżydowskich i upośledzoną ich resztę, podziału, który w znacznym stopniu pokrywał się z kategoriami krajowymi. Okupacyjne określenie „strona aryjska”

17 Zwany był małym traktatem wersalskim. W Polsce uważano go za „krzywdzący dla polskiej większości”, co wytworzyło odpowiednik niemieckiej Dolchstoßlegende - mitu o zadanym przez Żydów „ciosie w plecy”, który przyczynił się do narodzin nazizmu (Sala Rose, 2006, ss. 57-60). „Według nazistów wydarzeniem, które bezpośrednio wiąże się z działaniem środowiska żydowskiego, jest prośba o zawieszenie broni ze strony sztabu Armii Cesarstwa Niemieckiego na początku października 1918 roku, której bezpośrednią konsekwencją miało być podpisanie traktatu wersalskiego” („Legenda o ciosie w plecy”, b.d.; Marcuse, b.d.; Rosting, 1923).

18 Zob. np. opracowany przez gen. Grota-Roweckiego plan powstania powszechnego z 2 lutego 1941 roku uwzględniający ochronę Żydów, konieczną ze względu na ewentualną krytykę zagraniczną (Libionka, 2006, s. 27).

19 „Wiele lat później Jacek Kuroń chyba najlepiej opisał ówczesny mechanizm psychologiczny - wywieźli Żydów znaczy ICH wywieźli. Oddzielenie niezbędne dla zachowania zdrowia psychicznego" (Urban, 2013, s. 48). Prawdopodobnie chodzi o następujące sformułowanie Jacka Kuronia: „Część ludzi wybierała walkę z okupantem i pomoc Żydom. Pozostali mogli żyć normalnie i nie zwariować tylko wówczas, jeśli uznali, że Żyd jest inny i gorszy, jakby podczłowiek. W ten sposób propaganda hitlerowska zaspokajała pewne zapotrzebowanie. Myślę, że zetknięcie się z zagładą Żydów może człowieka doprowadzić albo do walki, albo do domu wariatów, albo uznania tych, którzy giną, za gorszych. I tak stało się z olbrzymią częścią polskiego społeczeństwa” (Kuroń, 1990, s. 26). Dziękuję Annie Bikont za pomoc w odszukaniu tego cytatu. 
nie było tylko przyswojeniem terminologii okupanta, ale określeniem doskonale zakorzenionym w polskim dyskursie politycznym ${ }^{20}$ i naukowym.

\section{Słownictwo prasy Związku Walki Zbrojnej - Armii Krajowej w początkach wojny}

Przejawem zobojętnienia generowanego (a może tylko wzmacnianego) przez narzucony system klasyfikacji było nie tylko słownictwo prasy tzw. narodowej, otwarcie wrogiej Żydom, ale także, co nas tu bardziej interesuje, słownictwo, jakiego w stosunku do Żydów używała prasa Związku Walki Zbrojnej - Armii Krajowej (ZWZ-AK) i Delegatury Rządu, analizowana przez Dariusza Libionkę.

Na poziomie językowym obserwujemy, że od początku wojny praktycznie nie pojawia się w tej prasie określenie „obywatel”, „obywatelski”. Polaków w gettach niemal wyłącznie określa się mianem „Żydów”, a kategoria obywatelskości nie pojawia się w kontekście ich praw, lecz wyłącznie w kontekście niewypełnianych przez nich obowiązków, kiedy występuje często z opprobrium „zdrady”. Na przykład, gdy mowa o ich poparciu dla Sowietów lub gdy wyraża się przekonanie, że będą nadal unikać „obywatelskiego udziału w walce o wolność przyszłego państwa Polskiego”, przygotowując się do „zaskoczenia społeczeństwa polskiego w decydującej chwili uboczną walką o najpełniejsze, nie tylko rewindykacyjne, lecz zdobywcze zabezpieczenie praw i interesów żydowskich w przyszłej Polsce” („Zagadnienie żydowskie”, 1941, ss. 2-4; cyt. za: Libionka, 2006, s. 35). Ponadto „pomiędzy położeniem Żydów a chrześcijan Polaków w GG istnieje kolosalna różnica na korzyść naturalnie Żydów" [raport Jerzego Prackiego przesłany do Londynu w lutym 1941 roku, pisany w okresie, gdy co prawda Żydów zamknięto w gettach, ale jeszcze nie wysyłano ich do Auschwitz czy rozstrzeliwano (Sprawozdanie Jerzego Piekarskiego z 20 lutego 1941 roku; cyt. za: Libionka, 2006, s. 25)]. Mogłoby się wydawać, że dokonane tu rozróżnienie „Żydzi”/ „chrześcijanie Polacy” jest neutralne, dotyczy wyznania, i że, budując je, autor stara się jak gdyby uwzględnić obywatelstwo Żydów. Jest to jednak tylko pozór. Gdyby cel naprawdę był taki, nazwano by ich po prostu „obywatelami polskimi wyznania mojżeszowego”, natomiast rozróżnienie „Polacy”/ „Żydzi” występuje w roli operatora dystansu. Efekt opiera się na dwuznaczności etnonimów „Polak” i „Żyd”, wzmacnianej niestabilnością małej/dużej litery w tym drugim słowie. Klasyfikator „Polak” może oznaczać 'obywatelstwo', tu jednak nie oznacza - wskazuje na to superlatyw „kolosalna różnica”, a także wtręt „naturalnie na korzyść Żydów”. Podobnie klasyfikator „Żyd”, który nominalnie określa wyznanie, działa jako sygnał obcości, uruchamiającej główny polski podział kulturowy, etniczno-religijny dominant cleavage [by użyć terminu Maksa Gluckmana (Gluckman, 1958)]. Gdy przeciwstawiamy sobie te dwa etnonimy, określenie „Żyd”

20 Zob. np. Teodor Jeske-Choiński, Program i metoda Żydów: „Z całą świadomością, kierując się bardzo chytrze, sprytnie obmyśloną metodą swoich wodzów, [Żydzi] burzą wspaniały gmach cywilizacji i kultury narodów aryjskich i chrześcijańskich, aby na jego gruzach zatknąć swój sztandar z Gwiazdą Salomona” (Jeske-Choiński, 1914, s. 17). „Żydowska krew zaraża aryjską krew i ducha”, autor podpisany „Swastyka” w „Pro Christo” z 1934 roku (cyt. za: Modras, 2004, s. 161). Leksyka tego rodzaju wzmacniana była słownictwem antropologii fizycznej, na którego omówienie brak tu miejsca. 
staje się tym, co profesor Ewa Bobrowska nazywa kakofemem - środkiem wywołującym niechęć do obiektu, do którego się odnosi (Bobrowska, 2007). Tym bardziej skutecznym, że spotka się z wysoką dyspozycją słuchaczy, którzy takich znaczeń tego słowa, jak „żydzić” w znaczeniu 'skąpić' albo „żydować” - ‘kolaborować' nabywali, jak mówią językoznawcy, „razem z akwizycją języka”"21.

Przyjrzyjmy się wydanej przez Biuro Informacji i Propagandy (BIP) we wrześniu 1942 roku (czyli już po deportacjach 300000 warszawskich Żydów do obozu śmierci w Treblince) broszurze Likwidacja getta warszawskiego, pióra pracownika BIP, Antoniego Szymanowskiego. Nominalnie autor chce „poruszyć opinię”, obudzić współczucie dla getta, mimo woli jednak wbudowuje zaporę dla tego współczucia, odsyłając żydowskich Polaków na wyznaczone im miejsce:

„Nie chcę kruszyć kopii w obronie zdrajców czy «cudzoziemców w ojczyźnie», ale [...] widziatem dzieło niemieckie”. „Mówiliśmy sobie [...] potworne są to metody, [...] ale w perspektywie politycznej, w perspektywie naszych polskich stosunków wewnętrznych może mieć to znaczenie raczej pozytywne. Bo przecież mieliśmy Żydów nieproporcjonalnie dużo, i to Żydów najzupełniej i na zawsze obcych naszej tradycji, naszej państwowości, naszej kulturze. [...] dziś wiem, że rozumowania takie są poniżej polskiej godności, poniżej naszej historii” (Libionka, 2006, s. 44, przyp. 142).

W trybie mowy pozornie niezależnej autor broszury przytacza tu wywód politycznego antysemityzmu (Bergmann, 1998), nie podejmując z nim dyskusji. Argumentację zastępuje apelem do uczuć, tudzież wzmianką o „polskiej godności”, co tylko konserwuje dyskurs. Tym, co pozostaje w nim nietknięte, jest wyobrażenie państwa narodowego, w którym mniejszość jest tolerowana dopóty, dopóki nie przekroczy wyobrażeń większości o tym, co „normalne” (Datner, 2007, s. 303). O faktycznej pozycji mniejszości w takim państwie informuje symptomatyczne „tylko”, które do dziś powraca w opisach przedwojennych realiów: „Według szacunków z roku 1931 w Drugiej Rzeczpospolitej Polacy stanowili tylko 64 procent populacji”22. Występkiem ze strony mniejszości może być nie tylko jej liczebność, obsadzanie niektórych ról, np. nauczyciela, krytyka lub reformatora - nie mówiąc o „nieprawidłowym” zaangażowaniu politycznym, głównie w komunizm (Datner, 2007, s. 303), ale w ogóle jej „widoczność”, jak w cytacie: „istniała potężna mniejszość, której niezasymilowana część raziła obcością wiary, języka i obyczaju, a część najbardziej zasymilowana - eksponowanym miejscem, jakie dzięki własnym talentom zajęła w kulturze polskiej" (Szpakowska, 2012, s. 229).

21 W powyższym akapicie inspirowałam się analizą dyskursu, zawartą w książce Marzeny Makuchowskiej Od wrogów do braci. Posoborowe zmiany w dyskursie Kościoła katolickiego (Makuchowska, 2011).

22 I dalej: „Co zaś do mniejszości żydowskiej - pamięć Zagłady sprawia, że postawy wobec Żydów, jakie w Drugiej Rzeczypospolitej dochodziły do głosu, budzą dziś często przerażenie. Sam problem jednak nie był stworzony sztucznie. Istniała przede wszystkim bieda, która sprawiała, że rozeźlona polska większość szukała sobie kozła ofiarnego; istniał ideologiczny i polityczny antysemityzm, a także polskie ambicje mocarstwowe; za oczywistość uważano wreszcie utożsamienie polskości z katolicyzmem. Ale zarazem istniały dysproporcje, które kłuły w oczy - nadreprezentacja Żydów w pewnych dziedzinach gospodarki, na przykład w handlu, i w pewnych zawodach inteligenckich, na przykład w prawie i w medycynie, oraz ich niedoreprezentacja gdzie indziej" (Szpakowska, 2012, s. 229). 
Ten sposób istnienia mniejszości, jaki polskim inteligentom zostawiła w spadku Druga Rzeczpospolita, możemy - za Adamem Zachary Newtonem - opisać jako incognito ergo sum (Newton, 2003, ss. 140-183). Mimo różnic politycznych i pochodzeniowych podzielało go i podziela przeważająca większość polskiego mainstreamu, w tym wielu żydowskich Polaków. Trudno się temu dziwić, skoro przyjęcie opisanego sposobu istnienia mniejszości było warunkiem jej akceptacji przez większość, której ambicją był, i jest, obraz zgody narodowej i atrybuty tolerancji.

\section{Incognito ergo sum}

„Gospodarzem w państwie polskim jest naród polski” - głosiła deklaracja OZN z roku 1937 (Strzembosz, 2000; cyt. za: Libionka, 2006, s. 59). Leksyka „gospodarz"/ "gość” podąża śladem słownictwa prasy narodowodemokratycznej, „traktowania Żydów nie jako równych, ale jako cudzoziemców, z wynikającymi stąd ograniczeniami” (Rudnicki, 2008, s. 70), a także Obozu Wielkiej Polski, który już w roku 1932 posługiwał się kategorią „przynależnych", tzn. osób pozbawionych praw wyborczych, niemogących zajmować stanowisk publicznych, niesłużących w wojsku itp. Kontynuację tego stanowiska odnajdujemy w stwierdzeniu Tomasza Strzembosza, że Polskie Państwo Podziemne było państwem „przede wszystkim Polaków, choć angażowali się w jego prace także liczni Białorusini, Żydzi, w mniejszym stopniu Ukraińcy. Było to więc jakby państwo szczególnie «polskie»" (Strzembosz, 2000, ss. 53-54; cyt. za: Libionka, 2006, s. 59). W opinii Strzembosza: „obywatelstwo Polskiego Państwa Podziemnego nie było tożsame ze statusem obywatela państwa polskiego”, co można by zapisać w postaci równania: „obywatele II RP” minus „obywatele Polskiego Państwa Podziemnego” równa się „Żydzi”. Żydowskich Polaków de facto uczyniono bezpaństwowcami.

Podobne wnioski wyciąga Dariusz Libionka: „od początku niemieckiej okupacji rzeczywistość na ziemiach polskich postrzegano w kategoriach etnicznych. ZWZ AK, choć w założeniach miała być organizacją «ogólnonarodową», była de facto organizacją narodu polskiego, realizującą narodowe cele i aspiracje" (Libionka, 2006, s. 54). W niektórych rejonach, jak w Okręgu Rzeszowskim czy we Lwowskiem żydowscy Polacy nie byli w ogóle przyjmowani do ZWZ, a na realia konspiracji w innych rejonach, np. w Kieleckiem rzucają światło słowa jednego z partyzantów: „W Armii Krajowej walczyli wyłącznie rdzenni Polacy. [AK] była organizacją czysto narodowo polską. Sporadycznie tylko pojawiali się w niej żydzi, którzy znajdowali w AK schronienie przed niemieckimi prześladowaniami" (Gruszczyński, b.d., s. 58). Ciekawą mediacyjną pozycję w tym dyskursie ustanawia słowo „ogólnonarodowe" pojawiające się w instrukcji nr 1 powołującej ZWZ. Czytamy w niej, że

„ZWZ jest organizacją ogólnonarodową, ponadpartyjną i ponadstanową, skupiającą w swych szeregach, bez względu na różnicę przekonań politycznych i społecznych, wszystkich prawych Polaków pragnących walczyć orężnie z okupantami w warunkach pracy konspiracyjnej i odpowiadających pod każdym względem wysokim moralnym wymaganiom, jakie stawia 
wobec jednostki podobna praca" (gen. Sosnkowski do płk. Roweckiego: powołanie do życia ZWZ. Instrukcja dla obywatela Rakonia z 4 grudnia 1939 roku; cyt. za: Libionka, 2006, s. 54).

Wydana 28 listopada 1939 roku londyńska uchwała Komitetu Ministrów do spraw Kraju zapowiadała zapewnienie sprawiedliwości, swobodnego rozwoju narodowego i opieki prawnej mniejszościom, które „wraz z narodem polskim wzięły udział w walce i pozostały wierne Państwu Polskiemu" (Libionka, 2006, s. 19). Powinny one (czytamy w instrukcji dla konspiratorów) walczyć ramię w ramię z większością, „pozostawiając [jednak] definitywne uregulowanie spraw mniejszości narodowych przyszłości i decyzji samego Narodu" (Libionka, 2006, s. 19). Zapis majuskułą nie pozostawia wątpliwości, o który naród chodzi.

W odezwie gen. Roweckiego do żołnierzy ZWZ z grudnia 1941 roku nie pojawiają się jednak żadne obietnice równości dla mniejszości narodowych w zamian za lojalność (Libionka, 2006, s. 34). Tendencję tę umacnia tekst opublikowany miesiąc później w „Rzeczpospolitej Polskiej", rozmywający kategorie obywatelskie na rzecz narodowo-religijnych. Zapowiada on:

„uregulowanie kwestii żydowskiej w sposób zgodny z chrześcijańskimi tradycjami polityki polskiej, a zarazem tak, aby przestała ona być czynnikiem, czyniącym z nas naród kaleki, dotkliwie cierpiący wskutek tego, iż dysproporcja w wielu dziedzinach naszego życia gospodarczego i kulturalnego spoczywa w obcych rękach” („Ku jakiej Polsce idziemy?”, 1942, ss. 2-3; cyt. za: Libionka, 2006, s. 34).

Na pozycję żydowskich Polaków w analizowanych przez Libionkę meldunkach i konspiracyjnych informacjach prasowych rzuca światło jedna z depesz szefa Komitetu Walki Cywilnej, Stefana Korbońskiego, wysłana do Londynu po rozpoczęciu Wielkiej Akcji. Depesza składa się z czterech zdań: pierwsze i drugie informuje o zniknięciu i rozstrzelaniu dwóch etnicznych Polaków, Adolfa Bnińskiego i rektora Tadeusza Pruszkowskiego, czwarte - o samobójstwie Adama Czerniakowa. Trzecie, równorzędne, brzmi: „Z getta wywożą na rzeź 7 tys. dziennie”, co historyk komentuje: „Los dwóch zasłużonych Polaków jawi się jako ważniejszy od masowego mordowania Żydów" (Libionka, 2006, s. 45). Od siebie dodam, że zważywszy energię, jaką poświęcono pojedynczym zwłokom doktora Franciszka Raszei, który pospieszył do pacjenta w getcie i 21 lipca 1942 roku został zastrzelony podczas udzielania mu pomocy (wspomina o tym pierwsza depesza Korbońskiego do Londynu), dysproporcja dotyczy zarówno żywych, jak i umarłych. Ciało zabitego lekarza z narażeniem życia przemycono na stronę „aryjską” i pochowano (Kalicki, 2008). Z caŁym szacunkiem dla poświęcenia doktora Raszei: w getcie takich ciał były wtedy setki, były to jednak ciała żydowskie. Oczywistość godziwego pochówku ciała nieżydowskiego można porównać tylko z oczywistością przypisania ciał żydowskich do dołów polewanych wapnem. Odbiciem segregacji za życia jest segregacja po śmierci, wyrażająca się W następującym fragmencie pamiętnika (z innego czasu i miejsca): „W jaki sposób spłacić dług względem Polaków pomordowanych w Ponarach? [...] Znaleźli się w dołach z masą ludzką obcą nam etnicznie" (Tych, 1999, s. 19). Pośmiertnej segregacji ciał zastrzelonych 
przez Niemców Ulmów z Markowej i ukrywanych przez nich Żydów też dokonali sąsie$\mathrm{dzi}^{23}$. Na tych przykładach ${ }^{24}$ widać tragiczną ironię rozmijania się losu „polskiego” i „żydowskiego". Nawet jeśli losy te połączyły się tak, jak to się stało w przypadku rodziny Ulmów oraz tych, którzy znaleźli u nich schronienie, żywi, segregując trupy, na powrót te losy rozdzielają, jakby kierował nimi dziwny, raczej niechrześcijański „lęk przed splamieniem". Ich zachowanie przypomina raczej rytuały chasydów unikających pochówku z Żydami niereligijnymi - „wolnomyślicielami lub kobietami”25. Żandarmi lub esesmani, którzy nadzorują taki pochówek, bez zastrzeżeń wyrażają zgodę na pośmiertną segregację, tak jak wcześniej Polacy bez zbędnych pytań zaakceptowali wprowadzony przez Niemców apartheid żywych, w złagodzonej postaci znany z Polski przedwojennej.

Dlaczego tak łatwo się z nim zgodzili, mimo że niemieckie klasyfikacje, podobnie jak późniejsza zorganizowana polska pomoc, objęły także tych Żydów, których, jak pisał Jan Karski, „w normalnych warunkach w ogóle za Żydów się nie uważało i którzy sami nie uważali się za Żydów" (Libionka, 2006, s. 51) ${ }^{26}$ ?

W uchwyceniu zmiany, jaką wprowadził okupant może być pomocne pojęcie „delegacji/uzurpacji”, którą wprowadza Pierre Bourdieu w Dystynkcjach (Bourdieu, 2005, s. 590). „Delegacja” jest czynnością, która mocą władzy państwowej legalizuje pewien stan faktyczny ze względu na wcześniejszy brak autoryzacji zwany przez badacza uzurpacją, nadaje mu nową nazwę i wyciąga z niej logiczne konsekwencje. Choć w przedwojennej Polsce kategorie segregacji działały w najlepsze, a procesy „odżydzania”27 - „aryzacji” zawodów, szkót, harcerstwa itp., higienicznej „samoobrony narodu”, którą ksiądz Michał Morawski nazwał „asemityzmem”28 - były powszechne, nie uzyskały jednak uprawomocnienia, a tym bardziej skutku porównywalnego z tym, który wiązał się z hitlerowską polityką rasową: Vereinigung i Vernichtung. $O$ ile Druga Rzeczpospolita stworzyła „problem

23 Mateusz Szpytma i Jarosław Szarek podają, że gdy sołtys Markowej, Franciszek Szylar, poprosił jednego z żandarmów o zgodę na osobny pochówek Żydów i katolików, Niemcy wyrazili zgodę (Szpytma \& Szarek, 2007, s. 58).

24 Por. też szyderstwo wobec matki Stefana Sawy, zamordowanego Sprawiedliwego z Zagórza pod Kielcami, z której morderca jej syna drwi, że „modli się nad żydowskimi kośćmi”: „To w tym czasie przyszedł do mieszkania Marasek Władysław [partyzant «Barabasza», jeden z wykonawców egzekucji w Zagórzu] i zaczął w mojej obecności opowiadać swojej matce Marii, że Sawa Michalina zebrała kości żydowskie, w trumnie przywiozła do domu, zaświeciła świeczki i modli się nad nimi" (Protokół przesłuchania świadka Florentyny Kobyłeckiej, WUBP Kielce, 22 stycznia 1951, IPN GK 306/44, k. 29, 30; cyt. za: Tokarska-Bakir, 2012, s. 239).

25 Zob. relacja Jerzego Spiry (Archiwum ŻIH, sygn. 301/2512), dotycząca sandomierskich chasydów: „Trzech starych Żydów, którzy obawiali się, że wypadnie im leżeć w grobie z ludźmi przypadkowymi, wolnomyślicielami, kobietami, zapłaciło esesmanowi, aby pozwolit im wykopać sobie samemu grób. Tenże esesman rozstrzelał ich nad grobem i razem zostali pochowani".

26 Zob. Bourdieu odsyłający do Henry Tajfela, Social categorization and similarity in intergroup behaviour (1973): „Psychologia społeczna pokazuje, że wszelki podział ludności na dwie grupy, jakkolwiek byłby arbitralny, wywołuje zachowania dyskryminacyjne, które usposabiają pozytywnie wobec członków własnej grupy, a niechętnie wobec członków innej, nawet jeśli godzi to jakoś w interes własnej grupy” (Bourdieu, 2005, s. 588, przyp. 19).

27 Por. z okresu jeszcze przed odzyskaniem niepodległości broszurę Z. Kościeszy, Jak się odżydzać? (Kościesza, 1913) czy artykuł ks. K. Czaykowskiego, Odżydzenie postępu (Czaykowski, 1910).

28 „Cóż więc zostaje do zrobienia względem Żydów - jeżeli nie chcemy ani antysemityzmu który przeciw nim judzi - ani filosemityzmu, który ich przyciąga? Zostaje jeszcze samoobrona społeczna przeciwko zgubnym wpływom elementu żydowskiego, którą bym nazwał asemityzmem. Tak ją nazywam, bo ta samoobrona nie mieści w sobie nic zaczepnego; zależy ona na tym, żeby społeczeństwo chrześcijańskie, przekonawszy się o zwykłej zgubności wpływu semickiego, zamykało się, zawarowywało przeciwko temu wpływowi - o ile być może, poza tym wpływem żyło i rozwijało się" (Morawski, 1896; cyt. za: Rudnicki, 2008, s. 65). 
żydowski”, udając, że go zaledwie opisuje ${ }^{29}$, hitlerowskie Niemcy znalazły dla niego „rozwiązanie". W różnych okresach w Drugiej Rzeczpospolitej dyskryminacja mniejszości i rasizm były praktyką początkowo nielegalną, następnie nieprawomocną, potem coraz częściej akceptowaną, ale (zapewne w związku z umowami międzynarodowymi, takimi jak wspominany już traktat o mniejszościach z 1918 roku) wciąż nieoficjalną. Nawet antysemicki OZN, choć popierany przez marszałka Rydza-Śmigłego, nie stał się (choć może tylko nie zdążyt) partią rządową, a żydowskim Polakom do końca Drugiej Rzeczpospolitej przynajmniej teoretycznie przysługiwała ochrona. Po uzyskaniu „delegacji” ze strony okupanta polskie „uzurpacje” klasyfikacyjne urzeczywistniły się w postaci muru getta.

Granice w przestrzeni są zawsze granicami w umyśle. „O tej ich sprawie” pisze Zofia Nałkowska w Dzienniku, gdy w getcie trwają walki (Tych, 1999, s. 32). „Jest to żydowska wojna" - uważa Roman Knoll w marcu 1940 roku (Libionka, 2006, s. 141, dok. 2), a następnie tłumaczy, w jaki sposób etniczni Polacy mogliby w kulturalny sposób się od niej zdystansować. „- Nas to nie czeka - tak jeden z polskich więźniów Auschwitz komentuje odesłanie grupy Żydów do gazu. - Dlaczego? - dopytuje się drugi. - My lepsi. - Dlaczego? - docieka tamten. - A tyś przypadkiem nie Żyd? Taki nos..." - słyszy w odpowiedzi (Timofiejew, 1960, s. 30; cyt. za: Tych, 1999, ss. 18-19).

Jeszcze ostrzejszą reakcję wywołuje odruch solidarności Michała Hajdo, uczestnika akcji ratowania Żydów, który na widok karuzeli na Placu Krasińskich traci panowanie nad sobą i zaczyna ubliżać stojącym wokół. „Reakcja gawiedzi była natychmiastowa. Obezwładniono mnie i z okrzykami «Ty żydowski pachołku, zaraz cię nauczymy», zaczęto wlec mnie w kierunku ulicy Bonifraterskiej”. Ale puenta tej historii dopiero nastąpi. Wyrwawszy się z rąk prześladowców, bohater zaczyna powątpiewać, czy byli oni „autentycznymi mieszkańcami okupowanej Warszawy" (Tych, 1999, s. 37).

Odruchem wykluczonego za bunt przeciw wykluczeniu etnicznemu okazuje się wykluczenie społeczne. W tej migawce odsłania się na chwilę twarz polskiego społeczeństwa czasów okupacji jako rozwarstwionego, zagrożonego rozpadem społeczeństwa poststanowego, które, aby odzyskać spójność, raz po raz sięgało po podobne wykluczenie (Zaremba, 2012, ss. $79-80)^{30}$.

\section{Powrót terminologii obywatelskiej}

Jak dowodzi Dariusz Libionka, terminologia obywatelska, praktycznie nieobecna w stosunku do żydowskich Polaków, niespodziewanie powraca na łamy polskiej prasy konspiracyjnej po wybuchu powstania w getcie. „Walczący obywatele Państwa Polskiego zza murów getta stali się bliżsi, niż bierne ofiary bez oporu dające się wlec na rzeź" - czytamy

29 O ideologicznej funkcji języka, który „definiuje swój przedmiot, udając że go opisuje” pisze Zygmunt Bauman (Bauman, 2009, s. 431).

30 W wywiadzie dla „Tygodnika Powszechnego” zwrócił na to uwagę Jan Tomasz Gross. Tłumaczył ową strukturą społeczną fakt nieprzeniknięcia do Warszawy informacji o masakrach podlaskich w lecie roku 1941 (Gross, 2004). 
w Biuletynie Informacyjnym z 29 kwietnia 1943 roku (Libionka, 2006, s. 83). Wtedy też dopiero padają wyczekiwane od początku wojny zdania:

„stojąc na gruncie państwowości polskiej, potępiamy zbrodnie niemieckie dokonywane na Żydach, nie tylko z pobudek humanitarnych i kulturalnych, lecz również dlatego, iż bezprzykładne, barbarzyńskie prześladowanie przez najeźdźcę Żydów, jako bądź co bądź obywateli państwa polskiego, godzi bezpośrednio w polską rację stanu. Bojownicy getta stanęli tedy na wysokości zadań obywateli polskich nie formalnie a faktycznie, broniąc swej godności i rozszerzając front walki z okupantem" (Getto walczy, Agencja Prasowa 28 kwietnia 1943 roku; cyt. za: Libionka, 2006, s. 83).

W wypowiedzi tej kryją się dwie implikacje. Po pierwsze, dopiero waleczność powstania w getcie daje żydowskiemu Polakowi akces do idiomu „polskości kulturowej”. Programem tego idiomu okazuje się „godność”. W jego rozumieniu godność ludzka nie jest dana, lecz zadana, uzyskuje się ją w trybie „walki”. Dopiero podjęcie walki sprawia, że żydowscy Polacy, którzy tylko formalnie byli dotąd obywatelami polskimi, stają się nimi faktycznie. Na tym przykładzie widać, że kategorie, które wykluczały ich ze wspólnoty, a następnie produkowały wobec nich obojętność, nie miały tylko charakteru etnicznego, lecz również kulturowy. Są to, jak powiedziałby Pierre Bourdieu, atrybuty szlachectwa kulturowego ${ }^{31}$.

Oprócz „godności” zalicza się do nich także pojęcie „pięknej śmierci”. Oto jej typowy opis zaczerpnięty z partyzanckiej literatury wspomnieniowej (dotyczy śmierci Władysława Jasińskiego, założyciela „Jędrusiów”):

„Kto widział śmiertelnie ugodzonego orła lub wykuty przed wiekami w kamieniu wizerunek rannej lwicy albo posąg umierającego wojownika gallijskiego, ten zrozumie głębię dramatyzmu śmiertelnych zmagań w chwili, kiedy było jeszcze do zrobienia wiele rzeczy ważnych, a siły przedwcześnie opuszczają po ciosach. Ale zrozumie także, że w niebo wzlecą inne orły, a w pole wyjdą liczne Iwy, a za broń chwycą nowi wojownicy" (Gruszczyński, 1995, s. 112).

A tak opisuje się okoliczności śmierci niepięknej, żydowskiej:

„jak bydło, jakby to nie byli ludzie [...] Żydzi szli tłumnie, przy znikomej asyście niemieckiej. Jakże żałośnie wyglądały te pochody smętnych postaci z piętnem śmierci w oczach, sunące biernie, pośpiesznym krokiem, ponaglane pokrzykiwaniem oprawców, poszturchiwane kolbami karabinów lub okładane harapami dla wymuszenia pośpiechu, zostawiając za sobą na drodze trupy zastrzelonych starców lub chorych [...]. A jednak często z tego konwoju potępieńców wyrywał się kierowany pod adresem znajomych Polaków okrzyk: «My dzisiaj, a wy jutro!» Może to dla pociechy własnej, może dla dodania sobie ducha w ten swoisty sposób, w każdym razie szli z tym zawistnym okrzykiem ginąć bez oporu" (Gruszczyński, 1995, s. 51) 32.

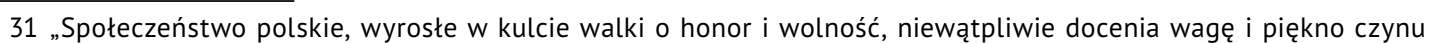
zbrojnego Żydów warszawskich i pragnie, by stał się on punktem zwrotnym w martyrologii i upodleniu, jakie za sprawą najeźdźców cierpi ludność żydowska na ziemiach polskich” (Libionka, 2006, s. 83).

32 Następuje odsyłacz do „Najjaśniejszej Rzeczpospolitej” z 10 kwietnia 1943 roku, w której Andrzej Ryman: „Rabini nakazali Żydom bierność powołując się na nauki proroka Abrahama i księgi Joba (w. 18). [...] Światowe żydostwo nie udzieliło pomocy pobratymcom. Jego postawa musiała więc podlegać jakimś nieujawnionym nadrzędnym dyrektywom [...]. Największa zagłada II wojny światowej pozostaje nieujawniona” (cyt. za: Gruszczyński, 1995, s. 51, przyp. 53). 
Próbę wyjaśnienia tragicznego rozmijania się żydowskiego i polskiego doświadczenia wojny ${ }^{33}$ podjęła Maria Hochberg-Mariańska we wstępie do zbioru Dzieci oskarżaja:

„W czerwcu 1945 roku spędziłam kilka godzin wśród dzieci z żydowskiego internatu w Zgierzu pod Warszawą. Chłopcy z najstarszej grupy mówili o swoich przeżyciach. Jeden z nich, którego zeznań nie notowałam i nie pamiętam nazwiska, opowiadał, jak to w obozie śmierci Birkenau nie było naczynia na upragnioną zupę z kotła, jak chleb rzucano im pod nogi, a marmeladę w twarz, a godzinę później dostawali miski, które pod grozą katowania trzeba było szorować do lśniącej czystości, aby po następny posiłek iść z gołymi rękami. Obecny przy rozmowie młody człowiek, który wojnę przeżył na «aryjskich papierach», wypowiedział o tego rodzaju obozowych przeżyciach swój sąd, sąd człowieka z honorem i godnością. Coś w tym sensie, że on nigdy by nie pogodził się z taką rzeczywistością i raczej zginął od razu niż... i tak dalej. Tamten chłopak, czternastoletni więzień Birkenau, powiedział na to: «Ale przecież ja naprzód byłem w getcie i przeżyłem wszystko»" (Hochberg-Mariańska \& Grüss, 1947, ss. X-XI).

\section{Epilog}

Żydowscy Polacy podlegali w czasie wojny podwójnemu wykluczeniu, które tłumiło odruchy pomocy. Pierwszym była ekspulsja poza margines wspólnoty narodowej, która wyparła obywatelską, co widzieliśmy, obserwując pracę klasyfikatorów w języku. Drugie wiązało się z charakterystycznym dla polskiego idiomu kulturowego etosem „walki o godność” i figurą „pięknej śmierci”. Przyłożona do żydowskiego losu, stała się potężną techniką adiaforyzacji - zobojętniania. Była nią w czasie wojny i ciągle na nas oddziałuje, deformując naszą pamięć i percepcję. Pozwala dostrzec tylko tych umierających, którzy mieszczą się w estetyce heroicznej. Pozostałych: głodnych, przerażonych i bezradnych, a także - jak dowodzi ostatnia debata prasowa dotycząca Festung Warschau Elżbiety Janickiej (Janicka, 2011; por. Czapliński, 2013) - ludzi o nieprawidłowych ciałach lub poglądach, „pozbawia twarzy”, to znaczy przedstawia jako obiekty, które „nie mogą stać się źródłem wymagań moralnych" (Bauman, 2009, s. 438). To, że dla Sprawiedliwych stali się oni jednak źródłem takich wymagań, było rezultatem samotnego buntu tych pierwszych przeciwko narodowym, społecznym i kulturowym wykluczeniom. Toteż do opisania wysiłku ratowania Żydów nie powinniśmy używać tych samych klasyfikacji, przeciwko którym Sprawiedliwi się zbuntowali. Jak mówił „Kazik” Ratajzer: „Oni działali na własny rachunek, reprezentowali sami siebie" (Rotem, 2013).

\section{Bibliografia:}

Bauman, Z. (1999). Modernity and the Holocaust (reprint.). Cambridge, New York: Polity Press.

Bauman, Z. (2009). Nowoczesność i Zagłada. (T. Kunz, Tłum.) (2. wyd.). Kraków: Wydawnictwo Literackie.

Bergmann, 0. (1998). Narodowa demokracja wobec problematyki żydowskiej w latach 1918-1929. Poznań: Wydawnictwo Poznańskie.

33 Podobne rozmijanie się Maria Janion określa mianem heterotelii (Janion \& Szczuka, 2013, s. 43). 
Bobrowska, E. (2007). Obrazowanie społeczeństwa w mediach. Analiza radiomaryjnego dyskursu. Kraków: Wydawnictwo Uniwersytetu Jagiellońskiego.

Bourdieu, P. (2005). Dystynkcja. Społeczna krytyka władzy sądzenia. (P. Biłos, Tłum.). Warszawa: Wydawnictwo Naukowe Scholar.

Bronner, S. J. (Red.). (2007). The Meaning of Folklore. The Analytical Essays of Alan Dundes. Logan: Utah State University Press.

Broszat, M. (1986). The Third Reich and the German People. W H. Bull (Red.), The Challenge of the Third Reich: The Adam von Trott Memorial Lectures. Oxford: Oxford University Press.

Brubaker, R. (2004). Ethnicity without Groups. Cambridge (Mass.): Harvard University Press.

Bujak, F. (1919). The Jewish Question in Poland. Paris. Pobrano z http://www.jrbooksonline.com/HTML-docs/ jewish_question_in_poland.htm

Czapliński, P. (2013, kwiecień 15). Rudy i Zośka 70 lat później. Estetyka i erotyka patriotyzmu. Gazeta Wyborcza.

Czaykowski, K. (1910). Odżydzenie postępu. Przegląd Powszechny, 108(2).

Czy Żyd może należeć do OZN. (1937). Gazeta Polska, 110.

Datner, H. (2007). Ta i tamta strona. Żydowska inteligencja Warszawy drugiej połowy XIX wieku. Warszawa: Żydowski Instytut Historyczny.

Deklaracja ideowo-polityczna Obozu Zjednoczenia Narodowego. (1946) (2. wyd.). Środkowy Wschód. Pobrano z www.polona.pl/dlibra/doccontent?id=26889\&from=FBC

Doroszewski, W. (1963). Słownik języka polskiego (T. 5). Warszawa: Wiedza Powszechna.

Dunin-Wąsowicz, K. (2013). Tłum patrzył na getto. Z prof. Krzysztofem Dunin-Wąsowiczem rozmawia Dariusz Nowik. Newsweek Historia, (4).

Gilman, S. L. (1986). Jewish Self-Hatred. Anti-Semitism and the Hidden Language of the Jews. Baltimore, London: The John Hopkins University Press.

Gluckman, M. (1958). Analysis of Social Situation in Modern Zululand. Manchester: Manchester University Press.

Grochowska, M. (2012). Ćwiczenia z niemożliwego. Warszawa: Wielka Litera.

Gross, J. T. (2004). Niepamięć zbiorowa. Tygodnik Powszechny, (32).

Gruszczyński, W. (b.d.). Lotna Sandomierska. Dzieje Oddziału partyzanckiego. b.m.

Gruszczyński, W. (1995). Odwet - Jędrusie: próba monografii. Staszów: Staszowskie Towarzystwo Kulturalne.

Hochberg-Mariańska, M., \& Grüss, N. (Red.). (1947). Dzieci oskarżają. Kraków: Centralna Żydowska Komisja Historyczna w Polsce.

Janicka, E. (2011). Festung Warschau. Warszawa: Wydawnictwo Krytyki Politycznej.

Janion, M., \& Szczuka, K. (2013). Niedobre dziecię. Warszawa: Wydawnictwo Krytyki Politycznej.

Jeske-Choiński, T. (1914). Program i metoda Żydów. Warszawa: Księgarnia „Przeglądu Katolickiego”.

Kalicki, W. (2008, kwiecień 22). Świadek tylko czyta. Gazeta Wyborcza. Pobrano z http://wyborcza. $\mathrm{pl} / 2029020,76842,5134852 . h t m l$ sms_code

kospa. (2013, maj 9). Krzysztof Dunin-Wąsowicz nie żyje. Był Sprawiedliwym wśród Narodów Świata. Gazeta Wyborcza. Pobrano z http://wyborcza.pl/1,75478,13877439,Krzysztof_Dunin_Wasowicz_nie_zyje_Byl_Sprawiedliwym.html\#ixzz2Snr0dU7F

Kościesza, Z. (1913). Jak się odżydzać? Poradnik dla wszystkich Polaków. Warszawa: Swój do swego. 
Krawczyk, A. (2012). Mały traktat wersalski. Stosunki Międzynarodowe. Pobrano z http://www. stosunkimiedzynarodowe.pl/ma\%C5\%82y-traktat-wersalski

Ku jakiej Polsce idziemy? (1942, styczeń 22). Rzeczpospolita Polska (2).

Kühne, T. (2011). Belonging and Genocide. Hitler's Community, 1918-1945. New Haven, New York: Yale University Press.

Kuroń, J. (1990). Wiara i wina. Do i od komunizmu. Warszawa: Niezależna Oficyna Wydawnicza.

Legenda o ciosie w plecy. (b.d.). Wikipedia.pl. Pobrano z http://pl.wikipedia.org/wiki/Legenda_o_ciosie_w_plecy

Libionka, D. (2006). ZWZ-AK i Delegatura Rządu RP wobec eksterminacji Żydów polskich. W A. Żbikowski (Red.), Polacy i Żydzi pod okupacja niemiecka 1939-1945. Warszawa: IPN.

Linde, S. B. (1951). Stownik języka polskiego (3. wyd., T. 3). Warszawa: PIW.

Majchrowski, J. (1985). Silni - zwarci - gotowi: myśl polityczna Obozu Zjednoczenia Narodowego. Warszawa: PWN.

Makuchowska, M. (2011). Od wrogów do braci. Posoborowe zmiany w dyskursie Kościoła katolickiego. Opole: Wydawnictwo Uniwersytetu Opolskiego.

Marcuse, H. (b.d.). Review of: Boris Barth, Dolchstosslegenden und politische Desintegration: Das Trauma der deutschen Niederlage im Ersten Weltkrieg, 1914-1933 (Düsseldorf: Droste, 2003). Pobrano z http:// www.history.ucsb.edu/faculty/marcuse/publications/reviews/BarthRev069.htm

Modras, R. (2004). Kościół katolicki i antysemityzm w Polsce w latach 1933-1939. (W. Turopolski, Tłum.). Kraków: Homini.

Morawski, ks. M. (1896). Antysemityzm. Przegląd Powszechny. Pobrano z http://www.ultramontes.pl/ asemityzm.htm

Newton, A. Z. (2003). Incognito Ergo Sum: 'Ex' Marks the Spot in Cahan, Johnson, Larsen, and Yezierska. W H. Hathaway \& et al. (Red.), Race and the Modern Artist. Oxford: Oxford University Press.

Prus, B. (1991). Lalka (T. 1). Wrocław: Zakład Narodowy im. Ossolińskich.

Rolke, T. (2013, maj 19). Ucieczka w modę. Z Tadeuszem Rolke rozmawia Jacek Tomczuk. Newsweek.

Rosting, H. (1923). Protection of Minorities by the League of Nations. The American Journal of International Law, 17(4). Pobrano z http://www.jstor.org/discover/10.2307/2188655?uid=3738840\&uid=2\&uid=4\&s id $=56278140963$

Rotem, S. (2013, kwiecień 20). Do dziś dręczy mnie myśl, czy wolno nam było. Gazeta Wyborcza.

Rudnicki, S. (2008). Asemityzm i jego skutki. W S. Rudnicki, Równi ale niezupetnie. Warszawa: Stowarzyszenie „Midrasz”.

Sala Rose, R. (2006). Krytyczny słownik mitów i symboli nazizmu. (Z. Jakubowska \& A. Rurarz, Tłum.). Warszawa: Wydawnictwo Sic!

Showalter, D. (1982). Little Man, What Now? Der Stürmer in the Weimar Republic. New York: Shoe String Press, Incorporated.

Stab-in-the-back myth. (b.d.). Pobrano z http://en.wikipedia.org/wiki/File:Stab-in-the-back_postcard.jpg

Strzembosz, T. (2000). Rzeczpospolita podziemna. Warszawa: Wydawnictwo Krupski i S-ka.

Szczotka, S. (b.d.). Wizerunek bolszewika w polskich plakatach propagandowych z wojny polsko-rosyjskiej 1919-1920 roku ze zbiorów Muzeum Niepodległości. Pobrano z http://www.muzeum-niepodleglosci.home. pl/konferencja/referaty_/8.\%20mgr\%20Sylwia_Szczotka_wizerunek_bolszewika.pdf

Szpakowska, M. (2012). „Wiadomości Literackie“ prawie dla wszystkich. Warszawa: W.A.B.

Szpytma, M., \& Szarek, J. (2007). Sprawiedliwi wśród narodów świata. Kraków: Dom Wydawniczy Rafael. 
Timofiejew, G. (1960). Człowiek jest nagi. Łódź: Wydawnictwo Łódzkie.

Tokarska-Bakir, J. (2012). Okrzyki pogromowe. Szkice z antropologii historycznej Polski 1939-1946. Wołowiec: Czarne.

Tych, F. (1999). Długi cień Zagłady. Szkice historyczne. Warszawa: Żydowski Instytut Historyczny.

Urban, J. (2013). Jerzy Urban o swoim życiu rozmawia z Martą Stremecką. Warszawa: Wydawnictwo Czerwone i Czarne.

Zagadnienie żydowskie. (1941). Wiadomości Polskie, (57).

Zaremba, M. (2012). Wielka trwoga. Polska 1944-1947. Kraków: Znak.

Zerubavel, E. (2006). Elephant in the Room. Silence and Denial in Everyday Life. Oxford: Oxford University Press.

Żuławski, Z. (1939). Refleksje. Warszawa: Wydawnictwo Komisji Centralnej Związków Zawodowych.

Żyndul, J. (2011). Kłamstwo krwi. Legenda mordu rytualnego na ziemiach polskich w XIX i XX wieku. Warszawa: Wydawnictwo Cyklady.

\section{Incognito ergo sum: on indifference}

Abstract: The present article is an analysis of various types of indifference of non-Jewish inhabitants of Warsaw to the plight of Jewish Poles. The words of Krzysztof Dunin-Wąsowicz, a historian and "Żegota" activist, provide the vantage point for the analysis: Dunin-Wąsowicz claimed that around 75 per cent of the inhabitants of Warsaw "were indifferent to what was taking place behind the Ghetto wall". Thomas Kühne hypothesised that it was Germans' indifference to the Jewish - not hatred - that legitimised the Nazi racial policies of the 1930s. This statement might also apply to the "75 per cent of the inhabitants of Warsaw". The article is mainly based on articles published by ZWZ-AK, in particular Biuletyn Informacyjny.

Keywords: Jewish Poles, non-Jewish Poles, indifference, Holocaust, witnesses-perpetrators-victims 